\title{
Cisplatin Transmucosal Patch
}

National Cancer Institute

\section{Source}

National Cancer Institute. Cisplatin Transmucosal Patch. NCI Thesaurus. Code C156155.

A transmucosal patch containing cisplatin, an inorg anic platinum agent, with potential antineoplastic activity. Upon mucosal application to the tumor site in the oral cavity, and upon subsequent release from the patch, cisplatin forms highly reactive, charged, platinum complexes which bind to nucleophilic groups such as GC-rich sites in DNA inducing intrastrand and interstrand DNA cross-links, as well as DNA-protein cross-links. These cross-links result in apoptosis and growth inhibition of tumor cells. 